\title{
The strategic and political consequences of using demographic criteria for the organization of European leagues
}

\author{
CHRISTOPHE DURAND ${ }^{1}$, LOÏC RAVENEL ${ }^{2}$, \& EMMANUEL BAYLE ${ }^{3}$ \\ ${ }^{1}$ CETAPS UPRES EA 2318, University of Rouen, France, ${ }^{2}$ CERSO VAR 6049 Thema, University of Franche-Comté, \\ France, ${ }^{3}$ CRIS UPRES EA 647, University of Lyon I, France
}

\begin{abstract}
The hypothesis of the Americanization of European club sports competitions has been the subject of much analysis. The main concept examined in this article is the growing reliance on demographic criteria, particularly the economic potential of the market zone. The purpose is to consider the consequences (rather than the likelihood) of a scenario in which demographic criteria become the sole variables of club location and their qualification in European championships. Such a change would have consequences for the both the private (shareholders or potential investors, direct supporters or general audience, sponsors, etc.) and public (federations, local government, states, European governing bodies) sectors.

The first part of the paper reviews the relevant demographic criteria in sports and then recalls the current strategies for league organization on both sides of the Atlantic. The second part is devoted to assessing the consequences of these strategies for those involved. General questions are then raised about the future of professional sports teams in Europe.

The analytical method is based on principles taken from demographics, geomarketing (as geographic information system, GIS) and the political economy of sport. The data concern six major leagues on both sides of the Atlantic.
\end{abstract}

Keywords: Professional sports, demographic, geographic, location, regulation

\section{Keypoints}

- The location of professional sports teams differs in Europe and North America.

- European organizational modes are changing by placing growing importance on demographic criteria for access to championships.

- Stakeholders and shareholders must adapt their policies to this revolution.

Two appreciably different operating models have often been observed in professional sports leagues. The North American model puts together franchised clubs that are expected to maximize financial profits. Championships thus take place only according to economic criteria regarding market access (Baade, 1996; Cocco \& Jones, 1997; Danielson, 2001; El Hodiri \& Quirk, 1974; El-Hodiri \& Quirk, 1971; Fort \& Quirk, 1992, 2004; Longley, 1995; Neale,
1964; Scully, 1995; Vrooman, 1995). Each team brings its local wealth to the network and contributes to the prosperity of all. One of the major factors in choosing a club location, either for relocation or expansion, is therefore the local economic potential and the quality of the sports facilities that can be offered to the potential league qualifier.

The European model emphasizes sports results achieved under balanced financial constraints. League organization is based on sporting criteria and operates according to a system of promotion/relegation at a national scale and on annual qualification at the European level (Bourg \& Gouguet, 1998; Caiger \& Gardiner, 2000; Gouguet \& Primault, 2003; Kesenne, 1996; Noll, 2002; Ravenel, 1998; Szymanski \& Smith, 1997; Vamplew, 1988; Walker, 1986). For the past 15 years, however, European sports have evolved considerably and the 'Americanization' of club championships has often been examined in the literature (Andreff, 2000; Andreff \& Staudohar, 2000; Bourg, 2003; Fort \& Quirk,

Correspondence: Christophe Durand, 76821 Mont St-Aignan CEDEX (or 2 rue des oiseaux 14610 Cambes France). Tel: 3302319577 45. E-mail: comedura@free.fr; Christophe.durand@univ-rouen.fr 
2002; Hoehn \& Szymansky, 1999; Kesenne, 2000, 2002; Lavoie, 2003; Szymanski \& Ross, 2002).

This article considers the consequences (and not the probability) of such a scenario for European sports producers. If the demographic variable often referred to as 'local potential' were to become determinant, the way leagues are organized in the Old Continent would be appreciably modified. The change would have powerful effects on all involved, whether from the private sector (shareholders or potential investors, supporters, sponsors, federations) or the public sector (local government, national government, European governing bodies). The commercial aspects and public acceptance of new policies will not be discussed, but the political aspects of this change will be explored.

Such a revolution, following an entire century of a fixed mode of operating, would substantially modify the power relationships and the governance of European professional sports. The organization of championships based solely on economic criteria would force many actors to adopt new strategies in a realm where the public sector and, more generally, the local community are major stakeholders. The reduced significance of national borders has already greatly modified the political economy of European professional teams, with the Bosman case in 1995. Closed multinational leagues, with the threat of private control, would be a second shock-wave whose consequences deserve careful study.

This article focuses on the question of whether the local potential of the trade area should become the key to championship qualification. The idea is not really new: in most other sectors of activity, the physical location of a commercial enterprise is a key to success. In the case of sports, mass consumption via television may be a given, but local, direct supporters are a significant and essential source of revenue. Moreover, this source has an impact on other club resources, as well (Andreff, 2000; Andreff \& Staudohar, 2000).

In the professional leagues, the networks of clubs participating in the same championships have tried to establish themselves in densely populated and economically wealthy geographic regions (Augustin, 1995; Bale, 1993; Danielson, 2001; Durand \& Bayle, 2002). Moreover, the collaboration among teams needed to produce balanced - and thus credible and saleable - championships, has pushed the leagues to look for a certain level of homogeneity in the qualifying clubs: the solidarity that is so vital is achieved by balanced contributions that ensure the prosperity of all.

In terms of method, our approach borrows rom demography, geomarketing (Geographic Information Systems) and the political economy of sports. The data presented concern sic major leagues on both sides of the Atlantic Ocean. Four North American major leagues are analysed (the NBA for basketball, NFL for American football, NHL for hockey and MLB for baseball). In Europe, football (soccer) and basketball are mainly considered.

The first part of this paper deals with two points. It reviews the concept of local potential in sports (IA) and defines the current strategies for league organization on both sides of the Atlantic (IB). The second part is devoted to the effects of these strategies. The consequences for all involved are first considered (IIA) and then general questions are raised regarding the future of European professional sports teams (IIB).

\section{The notion of local potential in professional sports}

A professional club has potentially four main types of client: direct supporters, corporate clients, local government and the media.

Historically, direct supporters have been the major financial resource. However, the ratio of revenues from this source has greatly declined since the sixties under the pressure of broadcasting and corporate clients (Andreff, 2000; Andreff \& Staudohar, 2000). Although their financial contribution has been reduced, direct supporters nevertheless remain the cornerstone of a professional club. Moreover, merchandising is still a powerful opportunity for big clubs to exploit their 'brand'. Beyond quantitative factors, the quality of direct, local supporters is a key factor in location. These supporters can be characterized by complementary variables: their disposable income and likelihood to support the team, and their propensity to consume. Throughout the world, sports producers have chosen (as far as possible) to "select" their direct supporters by raising ticket prices, thereby consigning the masses to watching the match on television.

Small businesses and corporations constitute the second type of client. Communication within and by means of sports has become a traditional method of promoting one's business. Business sponsors purchase advertising space in the vicinity of, and on, the playing field. These companies also commit to the purchase of public relations operations. For example, the creation of associated services (car park, restaurants, catering) also increases revenues. Although some clubs attract national or international brands as sponsors, the local presence of powerful companies is still a key element of success. These clients are relatively inelastic to prices and are generally solvent, offering a good market on a 
regional scale and even in some cases on a national scale. ${ }^{1}$

The third type of client, local authorities, is found all over the world. Their financial assistance and their involvement vary markedly from one country to another, from one sport to another, and according to the level at which the club competes (Durand \& Bayle, 2002). A powerful local government is a major condition for the choice of location. It ensures that the club will benefit in several key areas: the construction and maintenance of facilities (arenas, skating rinks, etc.), as well as direct and indirect financial help (tax exemptions, purchases of services, and so on).

In the United States, the debate on massive public financing of sports arenas has generated an abundant and often highly critical literature (Baade \& Matheson, 2001; Cagan, 1999; Coates \& Humphreys, 1999; Jones \& Walsh, 1988; Noll \& Zimbalist, 1997; Quirk \& Fort, 1999; Rosentraub, 1999; Ross, 1992; Siegfried \& Zimbalist, 2000). In Europe, the major financial crisis in the minor leagues or lower national divisions, which is related to wage inflation and the failure of media groups, has led governments to intervene to try to save their local team(s). Public financing (on the basis of tax breaks and/or legal aid) is justified on the grounds that a sports club is a source of local identity shared by the entire community.

The media (in particular, television broadcasters) are the fourth source of financing for professional clubs. The major broadcasting companies (whether pay-for-view or not) have become the principal clients of many clubs and even, in many cases, of the leagues. This has been achieved by means of collectively negotiated contracts. However, only a very few clubs and major leagues attract these clients, and the less prestigious clubs and the lower level championships benefit only through a system of solidarity. Thus, in principle, television rights may help to equalize the opportunities to attract national sports clubs, since location becomes less dependent on local potential.

The analysis of local potential must also take into account the competitive framework. Although, generally speaking, a sports club is in competition with other types of live performances and leisure activities, the local market is divided between the producers of various sports (or even various teams of the same sport). Thus, territorial monopoly is much sought after by the producers, even though -

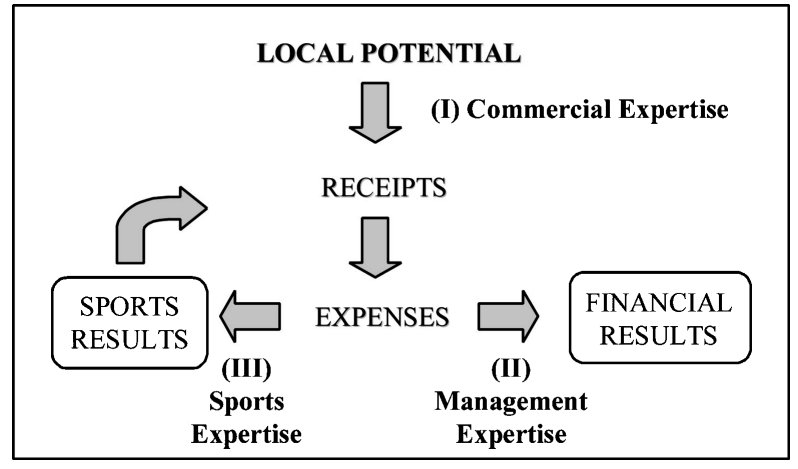

Figure 1. Three types of expertise for a professional sports team.

at least in principle - it is prohibited by the regulatory authorities.

The economic competition between clubs (even with substitutive activities) suggests the importance of examining the operation of three types of expertise, in addition to the strategy of local potential (which is by definition dependent on the environment). This is presented in Figure 1.

Commercial expertise (I) has the goal of transforming the available local potential into revenues. The available money is then used for production. Expertise in management (II) is dedicated to keeping expenditures within the estimated and strategic limits, which will determine the financial results. Last, sports expertise (III) is crucial to ensure the productivity of the committed expenditures. It should be noted that the sports results partially influence club revenues, with success in the field facilitating ticket sales.

The vital role of this triple expertise suggests that the correlation between local potential and sports and/or financial results is not absolute and that human know-how can compensate for environmental factors to some extent. A club with a powerful sales network, rigorous management and expert technical staff can compensate for a poor location. However, in the case of similar levels of expertise, location in a large rich city offers opportunities for better results. In fact, the current literature dealing with the relationship between financial expenditures and sports results shows overwhelmingly (Deloitte \& Touche, 2002; Durand, 1999; Levin, Mitchell, Volcker, \& Will, 2000; Ligue Football Professionnel, 2002; Noll, 2002; Szymanski \& Ross, 2000; Vamplew, 1988; Walker, 1986) that if money cannot do the whole job, it certainly helps!

\footnotetext{
1 The agreement between Manchester United and Nike, the sports equipment supplier, is an extreme case. The ten-year contract may yield more than 150 million euros. A shorter agreement between MU and Vodafone involves sponsoring shirts. For less prestigious teams, local business clubs often become privileged partners. In principle, these clubs have proved to be more faithful and sentimental in their choices and expectations.
} 


\section{Modes of organizing leagues}

Szymanski and Ross (2000)suggest that the fundamental difference between the structure of sports in the US and in the rest of the world, is openness.

\section{'Closed' North American leagues}

The North American leagues are, and have always been, organised according to economic criteria. A club's entry into a championship requires prior agreement by the already participating clubs and, independently, remaining in the league will depend on good financial health. Although teams were sometimes located in small East Coast cities up to World War II, this is no longer the case: for the past half century, the leagues have been structured on strictly demographic criteria.

A commercial strategy is thus essential. In the North American leagues, the emergence of new teams, the relocation of existing teams, and bankruptcies have all followed the economic trends of the country. North American major-league clubs locate in large metropolises, with a ratio of population to number of clubs to that varies from 1 to $4^{2}$ (Table I) (Figure 2).

For cities having only one or two teams, there is a threshold of approximately one million inhabitants, below which no city is likely to attract a major-league club. ${ }^{3}$ On the other hand, only three cities of more than one million inhabitants do not host at least one major-league club.

Despite the willingness to hold competitions between cities with comparable economic resources, disparities exist in terms of both potentials and the existing sports facilities. Moreover, tax and socioeconomic disparities among the different states have an impact, especially between Canada and the USA. The North American doctrine for regulating the leagues aims at rebalancing these disparities in order to maintain uncertainty about, and thus interest in the championships.

The leagues take into account both location (for either a new team or a relocating team) and the quality of the facilities. These two points are the central variables nowadays. When a league announces an opening in its network, local lobbying groups immediately arise to pressure local govern- ments to finance the construction of facilities capable of housing the newly admitted team.

The term 'closed league' is generally used for the American sports model. A closer look at the demographics of the American leagues nevertheless puts this term into clearer perspective: The composition of the championships is endlessly changing, testifying to the adaptability of the network. Whether it be club relocations or the creation of new franchises, the characteristics of the championships have shown strong fluctuations for more than a century (Danielson, 2001).

The clubs belong to a network because they need to collaborate to produce a competition. Once admitted to the championship, the newcomer is required to pay a sum of money that serves the dual function of compensating the other member clubs and opening up the network resources to the newcomer. ${ }^{4}$ This system is often compared to the franchising system in the trade or service sectors, which has operated for more than a century. It guarantees a permanent place in the championship for the investors, with no risk of being excluded for poor performance in competition.

\section{The European system of championship promotion and relegation}

In Europe, access to the major championships is based on competitive results (winning games). The system works by relegating the lowest-ranked teams to the lower divisions and promoting the leading teams of lower divisions to increasingly higher divisions.

This is true for all national sports in Europe. Thus, every year teams are confronted with the risk of being excluded from the biggest market. The system is the same for European-level competition: participation is based on the performance reached in the framework of the national leagues. However, in 1999 basketball in Europe underwent a revolution when a European league was created with access based not only on athletic criteria but also on a pluriannual invitation. The European Union of Basketball Leagues (ULEB), which was created in 1991, in fact instituted a 'private' competition for the first time in 2001. This competition operates outside the realm of the traditional federal powers and its access is partially reserved to a few invited clubs.

\footnotetext{
2 ( 1 to 3 if New York and Los Angeles are excluded).

${ }^{3}$ Note the exception of the Green Bay Packers of Green Bay, Wisconsin (fewer than 200,000 inhabitants).

${ }^{4}$ The sum varies with the league. The last four clubs admitted to the NHL paid $\$ 80 \mathrm{M}$ each in 1997 (compared to $\$ 50$ million in 1992 ). In the MLB the same year, Tampa Bay paid $\$ 135$ million whereas in 1995 , two newcomers paid $\$ 95$ million. Two NBA clubs created in 1994 paid $\$ 125$ million. The Cleveland NFL team created in 1998 cost its promoters $\$ 530$ million and this was only the entry fee. In this last case, the inflation was huge since two newcomers in 1993 had paid only $\$ 140$ million.
} 
Table I. Club location in USA Cities (rank 1 to 48) (2001, NBA, MLB, NFL, NHL, 2001).

\begin{tabular}{|c|c|c|c|c|c|c|c|}
\hline \multirow[t]{2}{*}{ Rank } & \multirow[t]{2}{*}{ Aire Metropolitaine } & \multirow[t]{2}{*}{ Population 1999} & \multicolumn{5}{|c|}{ Franchises $1999-2000^{\star}$} \\
\hline & & & Baseball & Basket & Hockey & Football & Total \\
\hline 1 & New York NY & 20137458 & 2 & 2 & 3 & 2 & 9 \\
\hline 2 & Los Angeles-Long Beach CA & 15971490 & 2 & 2 & 2 & & 6 \\
\hline 3 & Chicago IL & 8871473 & 2 & 1 & 1 & 1 & 5 \\
\hline 4 & Washington DC & 7357978 & 1 & 1 & 1 & 2 & 5 \\
\hline 5 & San Francisco CA & 6910027 & 2 & 1 & 1 & 2 & 6 \\
\hline 6 & Philadelphia PA-NJ & 5997338 & 1 & 1 & 1 & 1 & 4 \\
\hline 7 & Boston MA-NH & 5906195 & 1 & 1 & 1 & 1 & 4 \\
\hline 8 & Detroit MI & 5480630 & 1 & 1 & 1 & 1 & 4 \\
\hline 9 & Dallas TX & 4922135 & 1 & 1 & 1 & 1 & 4 \\
\hline 10 & Houston TX & 4499312 & 1 & 1 & & & 2 \\
\hline 11 & Atlanta GA & 3858546 & 1 & 1 & 1 & 1 & 4 \\
\hline 12 & Miami FL & 3713764 & 1 & 1 & 1 & 1 & 4 \\
\hline 13 & Seattle WA & 3478312 & 1 & 1 & & 1 & 3 \\
\hline 14 & Phoenix AZ & 3021874 & 1 & 1 & 1 & 1 & 4 \\
\hline 15 & Cleveland $\mathrm{OH}$ & 2913549 & 1 & 1 & & 1 & 3 \\
\hline 16 & Minneapolis-St. Paul MN-WI & 2866692 & 1 & 1 & 1 & 1 & 4 \\
\hline 17 & San Diego CA & 2832478 & 1 & & & 1 & 2 \\
\hline 18 & St. Louis MO-IL & 2571036 & 1 & & 1 & 1 & 3 \\
\hline 19 & Denver CO & 2411685 & 1 & 1 & 1 & 1 & 4 \\
\hline 20 & Pittsburgh PA & 2335624 & 1 & & 1 & 1 & 3 \\
\hline 21 & Tampa-St. Petersburg FL & 2287586 & 1 & & 1 & 1 & 3 \\
\hline 22 & Portland-Vancouver OR-WA & 2188866 & & 1 & & & 1 \\
\hline 23 & Cincinnati OH-KY-IN & 1962892 & 1 & & & 1 & 2 \\
\hline 24 & Kansas City MO-KS & 1754538 & 1 & & & 1 & 2 \\
\hline 25 & Sacramento CA & 1713756 & & 1 & & & 1 \\
\hline 26 & Milwaukee-WI & 1647162 & 1 & 1 & & & 2 \\
\hline 27 & San Antonio TX & 1564553 & & 1 & & & 1 \\
\hline 28 & Norfolk VI & 1549461 & & & & & \\
\hline 29 & Orlando FL & 1544455 & & 1 & & & 1 \\
\hline 30 & Indianapolis IN & 1534680 & & 1 & & 1 & 2 \\
\hline 31 & Columbus $\mathrm{OH}$ & 1482958 & & & 1 & & 1 \\
\hline 32 & Charlotte NC-SC & 1415871 & & 1 & & 1 & 2 \\
\hline 33 & Las Vegas NV-AZ & 1382124 & & & & & \\
\hline 34 & New Orleans LA & 1310657 & & & & 1 & 1 \\
\hline 35 & Salt Lake City UT & 1285294 & & 1 & & & 1 \\
\hline 36 & Greensboro NC & 1182172 & & & & & \\
\hline 37 & Nashville TN & 1176596 & & & 1 & 1 & 2 \\
\hline 38 & Buffalo-Niagara Falls NY & 1143636 & & & 1 & 1 & 2 \\
\hline 39 & Austin TX & 1141449 & & & & & \\
\hline 40 & Hartford CT & 1111485 & & & & & \\
\hline 41 & Raleigh NC & 1108900 & & & 1 & & 1 \\
\hline 42 & Memphis TN-AR-MS & 1103510 & & & & & \\
\hline 43 & Rochester NY & 1080743 & & & & & \\
\hline 44 & Jacksonville FL & 1064087 & & & & 1 & 1 \\
\hline 45 & West Palm Beach FL & 1052250 & & & & & \\
\hline 46 & Grand Rapids MI & 1049335 & & & & & \\
\hline 47 & Oklahoma City OK & 1048952 & & & & & \\
\hline 48 & Louisville KY-IN & 1004400 & & & & & \\
\hline
\end{tabular}

*Only franchises which are in the USA have been noted. Several Canadian teams should be added to complete this list (Vancouver, Toronto, Ottawa, ...). Only the Green Bay Packers, located in a city of less than one million people, does not appear.

Source: US Census Data.

Apart from this exception, the strategy described above has been followed in Europe for almost 50 years for football and 30 years for basketball, with specific features concerning the organization and hierarchy of championships. The following tables show the populations of the cities hosting a firstdivision club in soccer for the 2001/2002 season (Tables II-IV). It is worth noting that both small and big cities are represented and that a few big cities and their inhabitants are absent. 


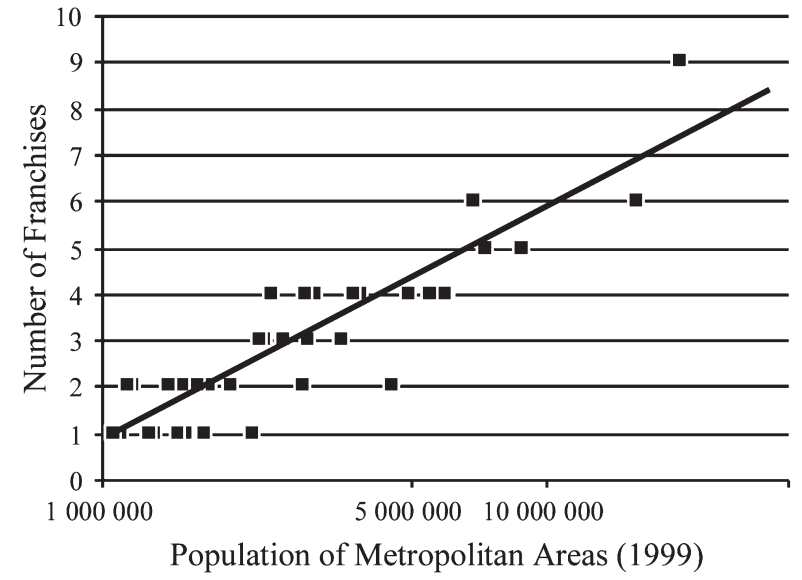

Sources : US Census Data

Figure 2. Population to number of clubs in the North American major leagues (2001).

When we correlated the populations of cities with the index of European success in soccer and basketball, ${ }^{5}$ several important elements emerged. First of all, the relationship among league membership, success and position in the urban population hierarchy was clearly verified: an increase in the size of the city was, on average, correlated with an increase in points. However, the relationship was not the same for the two sports. For soccer (Figures 3 and 4) a population threshold of about one million inhabitants can be noted, in addition to a strong correlation, above which the clubs are highly ranked.

Over a more recent period, the dominant role of Europe's largest cities is clearly observed in the UEFA Champion's League for soccer as can be seen in Table V.

Over the last eight seasons, no city of less than one million inhabitants has been at the top of the list. Rösenborg (16th in the list) followed by La Coruna, Monaco and Nantes are all good clubs but do not often appear, showing a total of only 15 cumulative participations. Valencia and its 1.5 million inhabitants is ranked 7 th with only three appearances despite excellent results (two finals and a quarterfinal).

As far as basketball is concerned, the relationship is less obvious (Figures 5 and 6). The data followed the hierarchical principle up to about one million inhabitants. However, no population threshold distinguishes the largest European cities and lower performances are even observed in the 1-to-2 million inhabitants range. Madrid, Barcelona, Milan and Athens have always been successful but the difference with other cities is not as marked as in football.

Over a more recent period, the club rankings after three years of the ULEB Euroleague show that the rules of this 'closed' basketball league allow some medium-sized cities to participate and even to put in respectable performances (Table VI).

This was the case for Treviso and Bologna, which are better rated than Barcelona (3rd), Athens (6th), Moscow (9th) and Madrid (10th). The Basque city of Vittoria (4th) ranks close to Piraeus, Bologna and Ljubljana. The trophy, however, has gone to Barcelona, Athens and Bologna. Although not statistically significant, this observation confirms the dominant position of the largest cities - or of the clubs that 'live' above their financial means: Bologna and especially Treviso (under administration since the spring of 2003) are in difficult financial straits.

In both sports, performances show a drop for the biggest cities (above 5 million inhabitants). Calculations were made for only four (London, Paris, Istanbul and Moscow) but, for the latter two, the economic impact was not in line with the number of inhabitants. ${ }^{6}$

Today, strong differences in the local potential of teams in the same league are a reality not only in all of Europe's national championships but also in all European-level competitions. In the United States, the leagues take into account the local potential in both the economic and athletic organization of championships in order to preserve competitive balance. In Europe, on the other hand, this strategy is ignored. However, under increasing pressure from reality and club demands, a complete change in strategy is likely. What would the major consequences of such a change be?

\section{Strategic consequences}

Four major elements may be underlined concerning both private investors and public actors.

\footnotetext{
${ }^{5}$ In football, the index of success is built according to a points system proposed by the world database, 'histora.org'. It synthesizes both the win rate and the rank achieved in the play-offs. The number of 'European points' is calculated for each club according to its results and the level of difficulty of the competitions. In order to limit the number of clubs, we considered only those clubs with more than 5 points and ended up with 251 clubs from 174 cities. For basketball, the proposed index is built from the database of European Cup results since the first match in 1958. We calculated the number of points obtained over this period by the clubs in the three European Cups on the basis of one point per null game and two points per winning game. Over 700 clubs have taken part at least once in these competitions, so we retained only those that obtained at least 20 points. This admittedly subjective criterion made it possible to limit the study population to 221 clubs.

6 The specific character of Greater Paris, with a great many sports clubs but few outstanding results, especially in football, also suggests an explanation for this drop in success. One might even hypothesize a second critical threshold, above which sports compete with a multitude of other leisure activities, although this remains to be demonstrated.
} 
Table II. Cities, populations, and teams in major-league soccer (Spain and Germany, 2001/2002).

\begin{tabular}{|c|c|c|c|c|c|}
\hline Metropolitan & $\begin{array}{l}\text { Population } \\
(\times 1000)\end{array}$ & $\begin{array}{c}\text { European in } \\
\text { Rank (1) }\end{array}$ & National Rank (2) & Terms in $2001-02$ & Pop/Teams \\
\hline \multicolumn{6}{|l|}{ SPAIN } \\
\hline Madrid & 4545 & 4 & 1 & Real Madrid, Rayo Vallecano & 2273 \\
\hline Barcelona & 3922 & 5 & 2 & FC Barcelona, Espanyol Barcelone & 1961 \\
\hline Valencia & 1288 & 29 & 3 & Valence CF, Villareal CF & 644 \\
\hline Sevilla & 952 & 44 & 4 & Real Betis, Sevilla FC & 476 \\
\hline Bilbao & 944 & 45 & 5 & Athletic Club Bilbao & 944 \\
\hline Malaga/Costa del Sol & 819 & 50 & 6 & Malaga CF & 819 \\
\hline Zaragoza & 604 & 72 & 8 & Real Zaragoza & 604 \\
\hline Las Palmas & 598 & 73 & 9 & UD Las Palmas & 598 \\
\hline Palma de Mallorca & 369 & 109 & 11 & Real Mallorca & 369 \\
\hline Valladolid & 350 & 113 & 12 & Real Valladolid & 350 \\
\hline Santa Cruz & 339 & 119 & 13 & CD Tenerife & 339 \\
\hline Vigo & 334 & 124 & 14 & RC Celta Vigo & 334 \\
\hline San Sebastian & 326 & 129 & 16 & Real Sociedad & 326 \\
\hline La Corogne & 314 & 139 & 19 & Deportivo La Coruna & 314 \\
\hline Pamplona & 248 & 178 & 21 & CA Osasuna & 248 \\
\hline Vitoria & 208 & 209 & 24 & Deportivo Alavés & 208 \\
\hline \multicolumn{6}{|l|}{ GERMANY } \\
\hline Rhein/Ruhr-Centrum & 4598 & 3 & 1 & FC Schalke 04, Borussia Dortmund & 2299 \\
\hline Berlin & 3624 & 7 & 2 & Hertha BSC & 3624 \\
\hline Rhein/Ruhr-WN-Düsseldorf & 2461 & 12 & 3 & VfL Borussia Mönchengladbach & 2461 \\
\hline Rhein/Ruhr-Köln/Bonn & 2147 & 17 & 4 & Bayer Leverkusen, FC Cologne & 1074 \\
\hline Hamburg & 2051 & 19 & 5 & Hamburger SV, FC Sankt Pauli & 1026 \\
\hline München & 1594 & 23 & 6 & Bayern Munich, Munich 1860 & 797 \\
\hline Stuttgart & 1138 & 35 & 8 & VfB Stuttgart & 1138 \\
\hline Bremen & 736 & 56 & 10 & SV Werder Bremen & 736 \\
\hline Nürnberg & 729 & 58 & 12 & FC Nürnberg & 729 \\
\hline Rostock & 253 & 175 & 28 & FC Hansa Rostock & 253 \\
\hline Freiburg im Breisgau & 204 & 212 & 33 & SC Freiburg & 204 \\
\hline Cottbus & 136 & 231 & 47 & Energie Cottbus & 136 \\
\hline Wolfsburg & 127 & 236 & 52 & VfL Wolfsburg & 127 \\
\hline Kaiserslautern & 98 & 259 & 75 & FC Kaiserslautern & 98 \\
\hline
\end{tabular}

\section{Clubs in medium-sized cities}

The establishment of major-league clubs in mediumsized cities (under the threshold of one million inhabitants) is likely to lead to failure. Admittedly, holding championships in cities of roughly the same size will lead to the creation of minor leagues in Europe. However, these championships, which would serve as training grounds for young players, will be largely excluded from the audio-visual market, unless a solidarity agreement exists between 'big' and 'little' clubs.

Private investors, much solicited in Europe since the nineties, have understood this. As already noted by Durand: "The operators have already shown their interest in the clubs playing in large urban centres despite the fact that other teams have presented better results in the championships" (Durand, 1999). In view of one day establishing NBA clubs in Europe, David Stern, the NBA commissioner, has been examining potential sites. He has not mentioned Pau-Orthez, Limoges, Vittoria or Treviso, although they are among the most famous teams in Europe, but instead is concentrating on the big cities like London, Paris and Berlin, none of which are particularly known for basketball! ${ }^{7}$

The local communities also face a dilemma. The construction of big, expensive and hard-to-manage facilities, which in some cases will be exclusively used by the professional team, is a risky undertaking in cities with fewer than a million inhabitants. Like North America (not including Mexico), Western Europe has about 50 cities with more than a million inhabitants (Table VII). This similarity in the demographic structure of about 300 million inhabitants makes the emergence of closed European leagues a real possibility. These leagues would

\footnotetext{
7 The newspaper, L'Equipe, Monday October 28, 2002, p.17. Another American league, the NFL, has already been established in Europe as the NFL-Europe and serves as a reservoir for its big sister on the other side of the Atlantic. This league is made up of six teams located only in big urban centers: the Amsterdam Admirals, who play in the Arena, one of most modern stadiums in Europe; the Glasgow Claymores; the Barcelona Dragons; the Düsseldorf Rhein Fire; the Frankfurt Galaxy and the Berlin Thunder.
} 
Table III. Cities, populations, and teams in major-league soccer (Italy and England, 2001/2002).

\begin{tabular}{|c|c|c|c|c|c|}
\hline Metropolitan Area & Population $(\times 1000)$ & European Rank (1) & National Rank (2) & Teams in $2001-02$ & Pop/Teams \\
\hline \multicolumn{6}{|l|}{ ITALY } \\
\hline Milano & 3907 & 6 & 1 & Inter Milan, Milan AC & 1953 \\
\hline Roma & 2986 & 10 & 3 & AS Roma, Lazio Rome & 1493 \\
\hline Torino & 1491 & 24 & 4 & Juventus, Torino & 745 \\
\hline Firenze & 958 & 43 & 5 & Fiorentina & 958 \\
\hline Bologna & 574 & 76 & 10 & Bologna FC & 574 \\
\hline Venezia & 471 & 86 & 12 & AC Venezia & 471 \\
\hline Bergamo & 343 & 118 & 14 & Atalanta Bergamo & 343 \\
\hline Brescia & 315 & 138 & 16 & Brescia Calcio & 315 \\
\hline Verona & 292 & 149 & 18 & AC Chievo, Hellas Verone & 292 \\
\hline Parma & 174 & 236 & 27 & Parma AC & 174 \\
\hline Lecce & 167 & 238 & 29 & US Lecce & 167 \\
\hline Perugia & 149 & 241 & 32 & AC Perugia & 149 \\
\hline Udine & 128 & 254 & 45 & Udinese Calcio & 128 \\
\hline Piacenza & 104 & 261 & 52 & Piacenza FC & 104 \\
\hline \multicolumn{6}{|l|}{ ENGLAND } \\
\hline Greater London & 7689 & 2 & 1 & $\begin{array}{l}\text { Arsenal FC, Chelsea FC, West Ham } \\
\text { United, Tottenham Hotspur, Charlton } \\
\text { Athletic, Fulham FC }\end{array}$ & 1281 \\
\hline Greater Manchester & 2341 & 14 & 2 & Manchester United, Bolton Wanderers & 1170 \\
\hline West Midlands & 2341 & 15 & 3 & Aston Villa & 2341 \\
\hline West Yorkshire & 1468 & 25 & 4 & Leeds United & 1468 \\
\hline Merseyside & 1028 & 40 & 5 & Liverpool FC, Everton FC & 514 \\
\hline Tyneside & 776 & 54 & 6 & Newcastle United & 776 \\
\hline Middlesborough & 580 & 75 & 9 & Middlesbrough FC & 580 \\
\hline Leicester & 409 & 94 & 12 & Leicester City & 409 \\
\hline Southampton & 270 & 162 & 20 & Southampton FC & 270 \\
\hline Derby & 218 & 198 & 26 & Derby County & 218 \\
\hline Sunderland & 201 & 217 & 29 & Sunderland AFC & 201 \\
\hline Blackburn & 141 & 238 & 38 & Blackburn Rovers & 141 \\
\hline Ipswich & 130 & 242 & 42 & Ipswich Town & 130 \\
\hline
\end{tabular}

integrate teams located only in the 50 largest cities, on condition that these latter agree to take on the burden of financing adapted facilities.

\section{Big clubs in smaller countries}

The big clubs in smaller countries will be handicapped by a limited national market (notably, televisual) and thus forced to band together or be absorbed into the championships of bigger countries, thereby excluding the smaller teams of these leagues.

This is now being observed throughout the world. See for instance the project to fuse the Austrian and Swiss football championships or the request of the Glasgow 'Old Firm' (Celtic and Rangers) to join the Premier League in England. The creation of an 'Atlantic' league, putting together the largest Portuguese, Dutch, Belgian and Danish clubs, is also now under consideration. The Anderlecht team, near Brussels, would like to join the French League Championship, an idea that is not that far-fetched given its political, geographic and linguistic proximity to France. The classic sports federations have up to now refused any exemption from the principle of club nationality (except for Monaco which plays in the French League), but pressure from the private operators is constant.

It also appears that the most balanced national championships provide less competitive clubs at the European level. The mechanism was described by Thomas Hoehn and Stefan Szymanski in these terms: "The interlocking system of leagues that currently operates in Europe is untenable because of the increasing dominance of competition in a Euroleague. Members of a Euroleague invest more in playing talent than the remainder of clubs, causing domestic leagues to become increasingly unbalanced. The most natural solution for this problem is for the Euroleague members to cease playing in the national leagues, thus making those competitions more balanced" (Hoehn \& Szymansky, 1999). ${ }^{8}$

\footnotetext{
8 The authors foresee the creation of a closed league made up of four conferences of 15 clubs each. The Southwest League would include four countries (France, Spain, Portugal, Belgium); the Northern League, seven (the Netherlands, England, Norway, Denmark, Scotland, Sweden, Finland); the Eastern League, 14 Eastern European countries; and, finally, the Central League would oppose Italian, German and Swiss clubs.
} 
Table IV. Cities, populations, and teams in major-league soccer (France, 2001/2002).

\begin{tabular}{|c|c|c|c|c|c|}
\hline Metropolitan Area & Population $\mathrm{n}(\times 1000)$ & European Rank ${ }^{a}$ & Nation I Rank ${ }^{\mathrm{a}}$ & Terms in $2001-02$ & Pop/Teams \\
\hline \multicolumn{6}{|l|}{ FRANCE } \\
\hline Paris & 9319 & 1 & 1 & Paris SG & 9319 \\
\hline Lyon & 1262 & 31 & 2 & Olympique Lyonnais & 1262 \\
\hline Marseille & 1231 & 32 & 3 & Olympique de Marseille & 1231 \\
\hline Lille & 959 & 42 & 4 & Lille OSC & 959 \\
\hline Bordeaux & 696 & 62 & 5 & Bordeaux FC & 696 \\
\hline Nantes & 496 & 84 & 8 & Nantes FCNA & 496 \\
\hline Lens & 323 & 130 & 16 & RC Lens & 323 \\
\hline Montpellier & 248 & 179 & 22 & Montpellier HSC & 248 \\
\hline Rennes & 245 & 181 & 23 & Stade Rennais FC & 245 \\
\hline Metz & 193 & 232 & 31 & FC Metz & 193 \\
\hline Troyes & 123 & 246 & 45 & ES Troyes & 123 \\
\hline Lorient & 116 & 249 & 48 & FC Lorient & 116 \\
\hline Belfort & 79 & 270 & 69 & FC Sochaux & 79 \\
\hline Monaco & 66 & 283 & 82 & AS Monaco & 66 \\
\hline Bastia & 53 & 309 & 108 & SC Bastia & 53 \\
\hline Auxerre & 42 & 331 & 130 & AJ Auxerre & 42 \\
\hline Sedan & 29 & 369 & 168 & CS Sedan & 29 \\
\hline Guingamp & 18 & 452 & 251 & Guingamp EAG & 18 \\
\hline
\end{tabular}

Source: Geopolis, B. Helleu.

${ }^{a}$ European Rank of the Metropolitan Area.

${ }^{b}$ National Rank of the Metropolitan Area.

Spain: no teams for Gijon (National Rank 7) and Cadiz (10).

Germany: no teams for Frankfurt (7), Dresden (9), Hannover (11).

Italy: no teams for Napoli (2), Genova (6), Palermo (7), Bari (8), Catania (9), Salerno (11). The economic break between the north and the south of Italy is very strong.

England: no teams for Sheffield (7), Nottingham (8), Bristol (10).

France: no teams for Nice (6), Toulouse (7), Toulon (9), Grenoble (10).

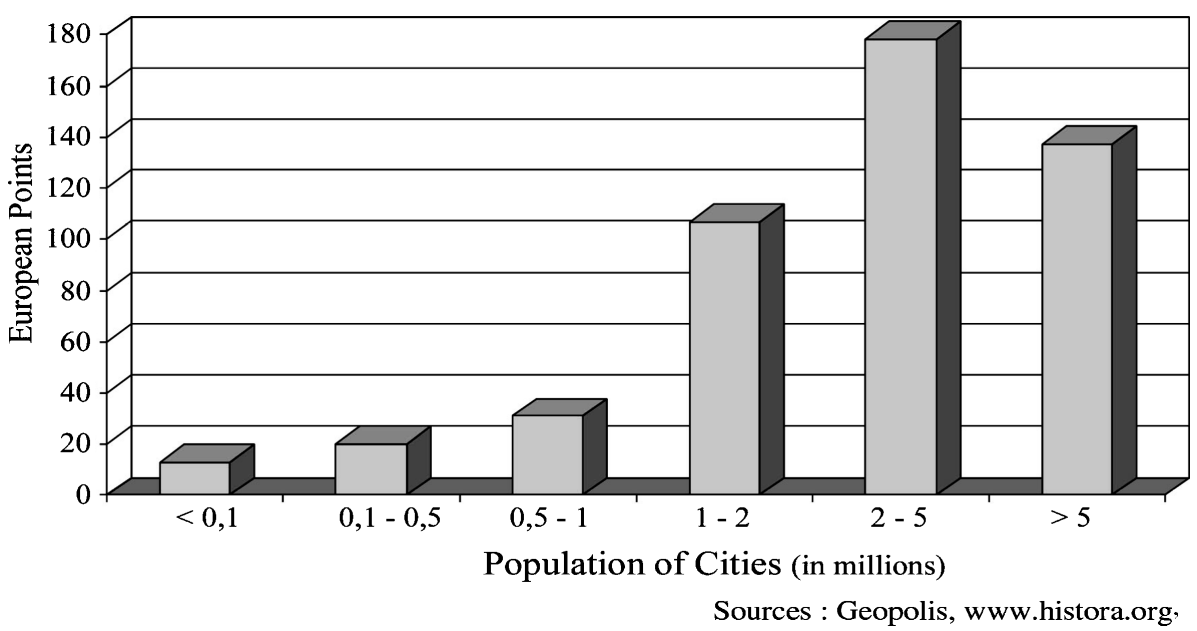

Figure 3. Size of the cities and successes in European soccer cups (1956-2001).

With the construction of a political Europe underway, these geographical groupings should appear as symbolically positive to the political authorities. The North American system of leagues divided into geographical 'conferences', with inter-conference confrontation, is a viable model from both a sporting and an economic point of view. ${ }^{9}$ This system is already well-established in the US. Such groupings in Europe would condemn the weakest clubs to the role of 'also rans', at best they would play a subsidiary role of training young players in lowerlevel championships. Without the opportunity to access the principal market, these clubs would remain at the second or third levels.

\footnotetext{
9 The political homogeneity of the United States has limited the extension of clubs to only seven Canadian franchises. The establishment of clubs in Mexico or Puerto Rico has encountered difficulties because of very different levels of prosperity.
} 


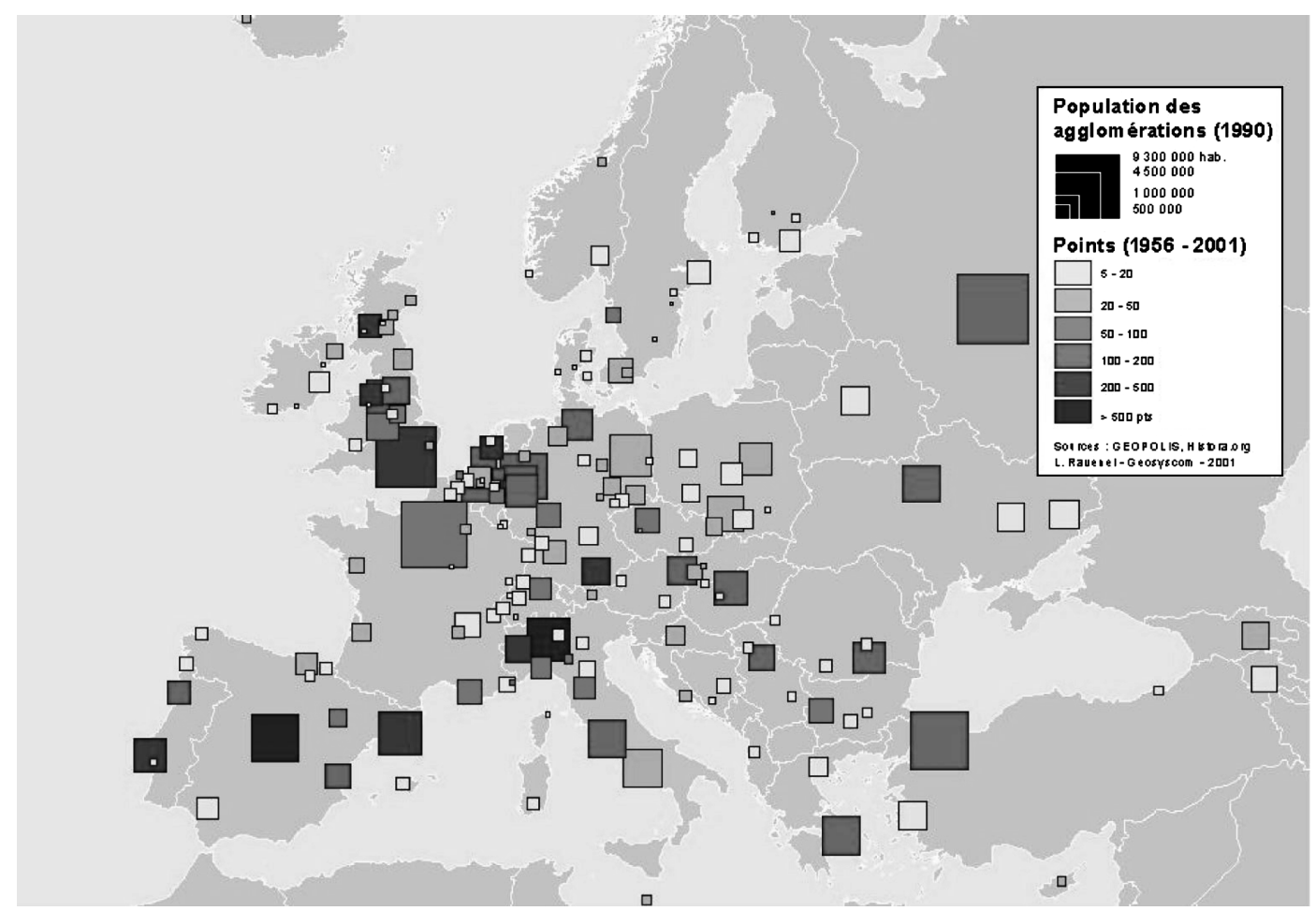

Figure 4. (Map) European cities and athletic successes in European soccer matches (1956-2001).

Table V. Participation, trophies and overall performance in European championship cups in soccer (1995/2003).

\begin{tabular}{llccc}
\hline Team & Nat. & Team Points & App. & 1st \\
\hline Real Madrid & Esp & 178 & 7 & 3 \\
Juventus Turin & Ita & 112 & 7 & 1 \\
Bayern Munich & Ger & 105 & 7 & 1 \\
Manchester United & Eng & 94 & 8 & 1 \\
Milan AC & Ita & 70 & 5 & 1 \\
Ajax Amsterdam & Ned & 63 & 6 & 1 \\
FC Valencia & Esp & 54 & 3 & \\
Borussia Dortmund & Ger & 53 & 6 & 1 \\
FC Barcelona & Esp & 37 & 7 & \\
Bayer Leverkusen & Ger & 35 & 5 & \\
Dynamo Kiev & Ukr & 28 & 8 & \\
Panathinaïkos Athens & Gre & 19 & 5 & \\
Inter Milan & Ita & 18 & 3 & \\
FC Porto & Por & 17 & 7 & \\
Galatasaray Istanbul & Tur & 17 & 7 & \\
Rosenborg Trondheim & Nor & 16 & 8 & \\
Deportivo La Coruna & Esp & 15 & 3 & \\
Arsenal (London) & Eng & 14 & 5 & \\
Paris Saint-Germain & Fra & 14 & 3 & \\
AS Monaco & Fra & 13 & 2 & \\
Spartak Moscow & Rus & 13 & 8 & \\
Leeds United & Eng & 12 & 1 & \\
FC Nantes & Fra & 11 & 2 & \\
Olympiakos Pireus & Gre & 11 & 6 & \\
\hline So : & & & &
\end{tabular}

Source : UEFA.

\section{Competition in the same sports}

The creation of leagues based on economic criteria will threaten the survival of other types of competition in the same sport: the Olympic Games, World or European Championships, National Cups, and so on. In particular, this raises the issue of the timing of these competitions with respect to league schedules. In other words, it raises questions about the sports calendar.

Currently, American league players compete for their national teams on a voluntary basis ... and with the agreement of their employers. This question, which is crucial in hockey and basketball, seems to be becoming more sensitive in football and rugby.

Within the same sport, the organizing bodies such as the IOC, the international federations, the continental confederations, the public or private national leagues and the 'historic' national sports federations, may all be considered as mutually competitive. They all have to share the same market. The multiplication of competitive events, which devours days in the athletic season, may lead (in the long term) the clubs (or their players) to participate only in selected competitions. ${ }^{10}$

${ }^{10}$ In 2000, Manchester United withdrew from the English FA Cup to take part in the new CLUB world championship organized in Brazil by FIFA. Some clubs are already forced to send their reserve team to certain matches, national cups in particular, because they cannot keep up with the competition schedule. 


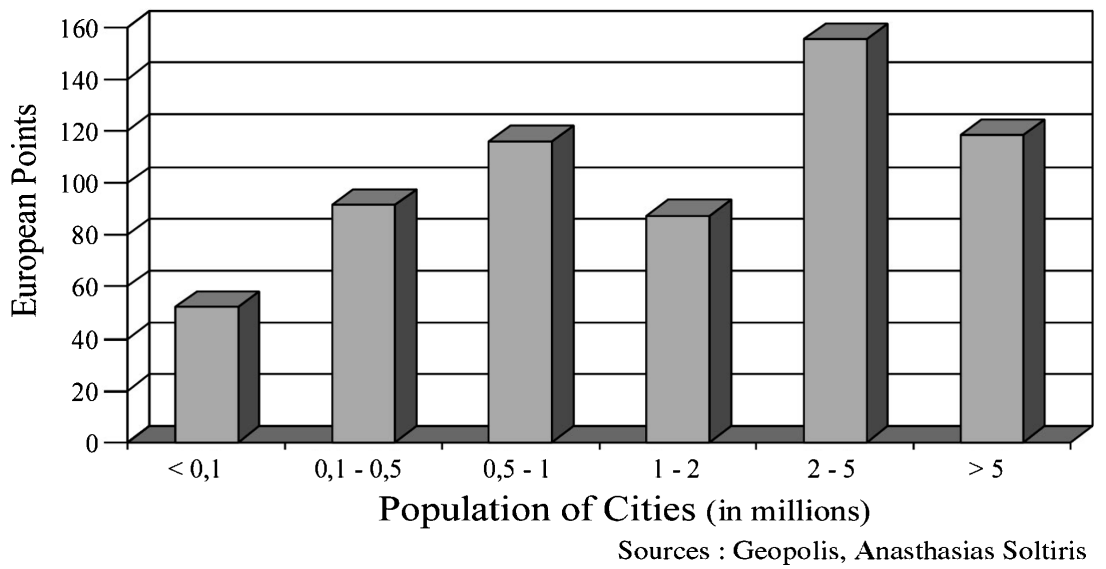

Figure 5. Size of the cities and successes in European basketball cups (1957-2001).

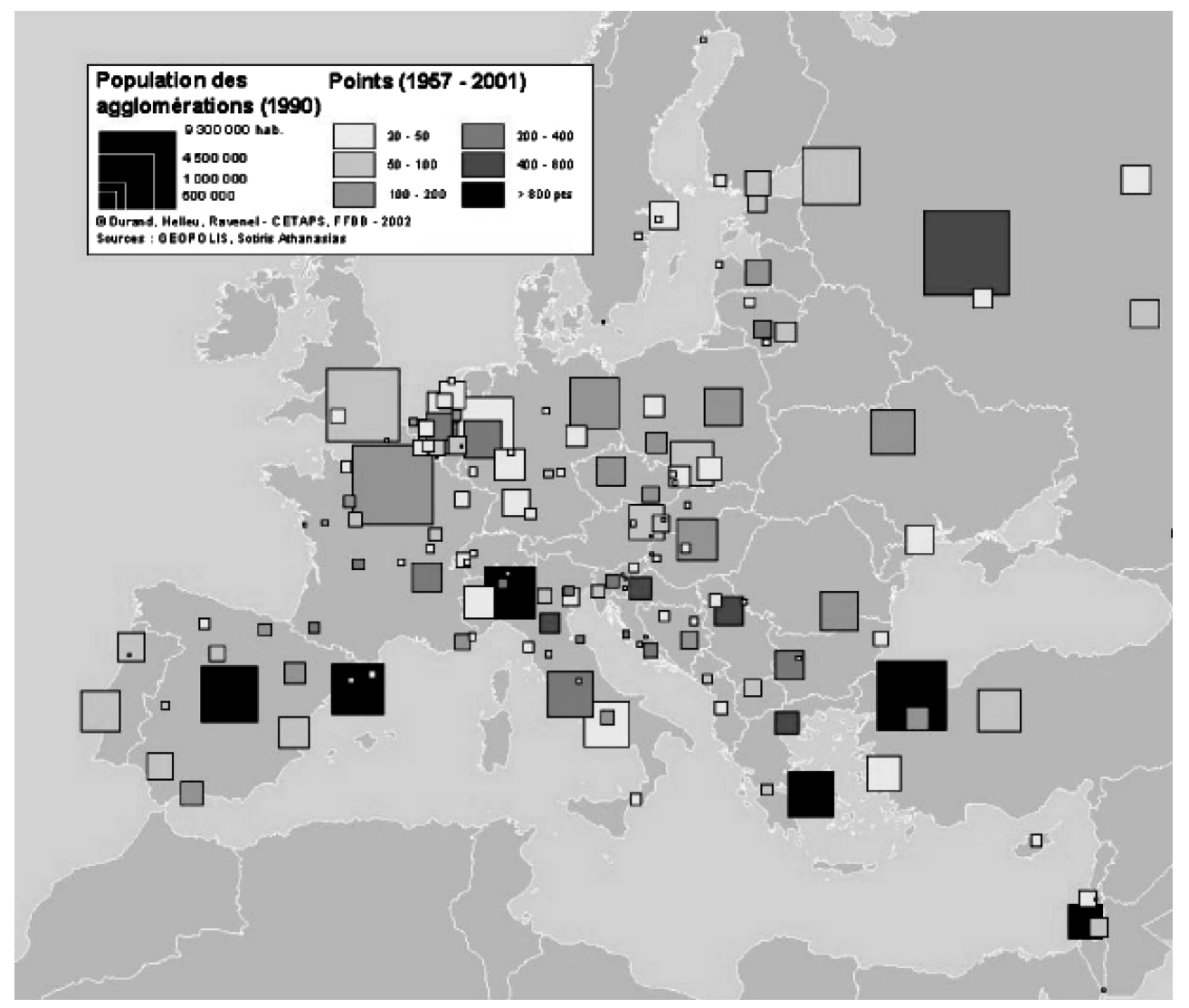

Figure 6. (Map) European cities and success in European basketball cups (1957-2001).

\section{Demographic structures}

The demographic structure of certain countries and/ or their slow economic development will permanently split the European continent. The GDPs of the 15 European Member States (pre 2004) show major disparities (Behrens, 2003). ${ }^{11}$ The GDP per capita varies by a ratio of 1 (Greek region of Ipeiros) to 5 (Inner London). Within a given country, the data show considerable variations. In Germany (with an average value of 106), the mean value is 182 for the inhabitants of the Hamburg region while that of Brandenbourg barely reaches 69. In Metropolitan France, the value varies from 158 in the Paris region to 81 in Nord Pas-de-Calais. The figures concerning the Acceding States entering the European Union in May 2004, confirm the disparities in economic

11 The document provides data for the 212 regions, NUTS level 2, of the 15 Member States (pre-2004) and the 56 regions of the 10 New Member States (methodological limitations related to inter-region worker flows do not negate the lessons to be drawn from this document). 
Table VI. Participation, trophies, and overall performance in the ULEB basketball cup (1999/2002).

\begin{tabular}{|c|c|c|c|c|c|}
\hline Rank & Team & Country & App. & $1 \mathrm{st}$ & Points \\
\hline 1 & Pallacanestro Treviso & ITA & 3 & 0 & 84 \\
\hline 2 & Virtus Bologna & ITA & 3 & 1 & 84 \\
\hline 3 & FC Barcelona & ESP & 3 & 1 & 80 \\
\hline 4 & Saski Baskonia Vitoria & ESP & 3 & 0 & 78 \\
\hline 5 & Olympiakos Piraeus & GRE & 3 & 0 & 66 \\
\hline 6 & Panathinaikos Athens & GRE & 2 & 1 & 66 \\
\hline 7 & Fortitudo Bologna & ITA & 3 & 0 & 66 \\
\hline 8 & Olimpija Ljubljana & SVN & 3 & 0 & 62 \\
\hline 9 & CSKA Moscow & RUS & 2 & 0 & 56 \\
\hline 10 & Real Madrid & ESP & 3 & 0 & 56 \\
\hline 11 & Maccabi Tel-Aviv & ISR & 2 & 0 & 48 \\
\hline 12 & Efes Pilsen Istanbul & TUR & 2 & 0 & 48 \\
\hline 13 & AEK Athens & GRE & 3 & 0 & 48 \\
\hline 14 & Ulker Istanbul & TUR & 2 & 0 & 44 \\
\hline 15 & Cibona Zagreb & $\mathrm{CRO}$ & 3 & 0 & 34 \\
\hline 16 & Zalgiris Kaunas & LTU & 3 & 0 & 32 \\
\hline 17 & AS Villeurbanne-Lyon & FRA & 2 & 0 & 30 \\
\hline 18 & CB Malaga & ESP & 2 & 0 & 28 \\
\hline 19 & EB Pau-Orthez & FRA & 2 & 0 & 26 \\
\hline 20 & Buducnost Podgorica & SBM & 3 & 0 & 24 \\
\hline
\end{tabular}

Source : ULEB.

development both within and between countries. Thus, only four of the 56 regions of applicant countries are above $75 \%$ of the continental average (15 Member States of the EC plus 10 Acceding States). Some regions of Romania present a GDP per capita that is $18 \%$ of the average value. ${ }^{12}$

Another problem might primarily concern French clubs. France has a very specific urban demography: a very small number of big cities (populations greater than 1 million) in comparison with the total population. Although Paris is the largest city in Europe, there are only three cities with more than a million people: Lyon, Marseilles and Lille. This characteristic cannot be fully compensated by either the presence of strong national television broadcasters or the economic prosperity of quite a few French regions. ${ }^{13}$ This aspect is worrisome for the future, since very few French clubs would fulfill the economic conditions for joining the newly created major leagues. ${ }^{14}$

This intra-continental economic imbalance would be markedly accentuated by leagues built on economic criteria. The recent evolution of the UEFA Champions' League has already shown this. Although no club will be completely excluded from competition, access to the final games (play-offs, finals) is practically reserved for the teams of the three dominant countries (England, Spain and Italy). This last point calls our attention to the political dimension of an 'Americanisation' of European leagues.

\section{Questions for the future}

The predominance of demographic criteria in Europe would probably engender commercial and mainly political problems. Championships between teams coming essentially from the four or five biggest and richest Western European countries would emphasize the already existing fracture in the enlarged European Union, at a time when it should be striving for homogeneity. In response, governments could insist on adapted conditions of access for clubs located in less prosperous regions. This would provide an opportunity for cities in which sports are of particular social importance to compete honourably in a major European league. Moreover, the future of national competition comes under question in a context dominated by the internationalization of both team constitution and club competition.

\footnotetext{
12 Only the national figure is available for Turkey, 28. The Baltic countries, which have traditionally trained basketball players, have values of 34 (Latvia), 39 (Lithuania) and 44 (Estonia), all appreciably lower than those of Western Europe.

${ }_{13}$ These cities rank, respectively, 34th, 35th and 44th in Europe. The fifth largest French city, Bordeaux, and its 700,000 inhabitants are 61 st in Europe in terms of population.

${ }^{14}$ Moreover, high taxes and social security costs handicap French companies. Lobbying for a system of exemptions is at the heart of the activities of the leaders of French professional sports.
} 
Table VII. Populations of European cities (with more than 1 million inhabitants).

\begin{tabular}{|c|c|c|}
\hline Rank & Paris & Pop $1990(\times 1000)$ \\
\hline 1 & Paris & 9319 \\
\hline 2 & Moscou & 8642 \\
\hline 3 & Grand Londres & 7689 \\
\hline 4 & Istanbul & 5476 \\
\hline 5 & $\begin{array}{l}\text { Rhein/Ruhr-Centrum } \\
\text { (Dortmund, Schakle } 04, \ldots \text { ) }\end{array}$ & 4598 \\
\hline 6 & Madrid & 4545 \\
\hline 7 & Barcelona & 3922 \\
\hline 8 & Milano & 3907 \\
\hline 9 & Berlin & 3624 \\
\hline 10 & Athènes & 3027 \\
\hline 11 & Napoli & 3026 \\
\hline 12 & Roma & 2986 \\
\hline 13 & Kiev & 2577 \\
\hline 14 & Düsseldorf & 2461 \\
\hline 15 & Budapest & 2449 \\
\hline 16 & Birmingham & 2341 \\
\hline 17 & Greater Manchester & 2341 \\
\hline 18 & Lisboa & 2315 \\
\hline 19 & Köln/Bonn & 2147 \\
\hline 20 & Warszawa & 2083 \\
\hline 21 & Hamburg & 2051 \\
\hline 22 & Bucuresti & 1976 \\
\hline 23 & Bruxelles & 1845 \\
\hline 24 & Wien & 1746 \\
\hline 25 & München & 1594 \\
\hline 26 & Stockholm & 1587 \\
\hline 27 & Torino & 1491 \\
\hline 28 & Leeds/Bradford & 1468 \\
\hline 29 & Frankfurt am Main & 1355 \\
\hline 30 & Rotterdam/Dordrecht & 1342 \\
\hline 31 & Kobenhavn & 1337 \\
\hline 32 & Valencia & 1288 \\
\hline 33 & Beograd & 1268 \\
\hline 34 & Lyon & 1262 \\
\hline 35 & Marseille & 1231 \\
\hline 36 & Praha & 1212 \\
\hline 37 & Porto & 1149 \\
\hline 38 & Stuttgart & 1138 \\
\hline 39 & Sofija & 1129 \\
\hline 40 & Groot Amsterdam & 1083 \\
\hline 41 & Glasgow & 1067 \\
\hline 42 & Antwerpen & 1045 \\
\hline 43 & Liverpool & 1028 \\
\hline 44 & Lodz & 1023 \\
\hline
\end{tabular}

Source : GEOPOLIS.

The idea of a mixed North American and European model has sometimes been raised. Bourg (2003), for example, suggested the possibility "of a competition founded by 24 clubs automatically qualified according to the criteria of the UEFA and 8 clubs selected on the basis of the results of the national championships. This structure is very similar to the so-called Intertoto." 15 We are somewhat sceptical, however, about a structure that has never been tested. Indeed, the access of eight clubs based on sporting performance criteria would contribute to an imbalance in the national championships. It is also highly improbable that these clubs (allowed to play against the 'top teams') would really be competitive 'on the field'.

In any case, many observers have concluded that a close link between national and European competition is no longer tenable because this necessarily implies competitive imbalance in the national championships. This phenomenon is detrimental for both the 'big teams', who cannot find credible opponents, and the smaller teams, who are increasingly confined to the role of making others look good.

As is often the case, the change in criteria is occurring without apparent rupture, but instead is being accomplished by a slow and almost unconscious social transition. Nevertheless, this 'smooth' change is the result of constant club pressure on the 'historic' federal authorities and sometimes of lobbies like G14, a confederation of the 20 most powerful football clubs in Europe. Fortunately, a rupture has up to now been avoided... and instead a quiet revolution is underway, without major political crises and with all concerned parties avoiding detrimental clashes.

The structure of professional sports has been shifting since the early nineties. As mentioned by Bourg (2003): "the link between sport and territory will be questioned." As in the United States, we will possibly observe the geographic mobility of clubs in search of the best financial package for their owners (Bourg \& Gouguet, 1998). The future will not be a prolongation of the past but instead is already forcing us to completely rethink professional sports for a new century. The permeability of borders and changing concepts of nationality will redistribute the cards in Europe and lead to new formulae, better adapted to the constraints and structures of the Old Continent.

The role of the European nations and, in the last analysis, of public opinion will probably be more pronounced than it is in North America. This will bring to the debate social and political dimensions that are likely to interfere with the economic aspects of the issue.

\section{References}

Andreff, W. (2000). L'évolution du modèle européen de financement du sport professionnel. Reflets et Perspectives de la Vie Économique, 2-3, 179-191.

Andreff, W., \& Staudohar, P. (2000). The evolving European model of professional sports finance. Fournal of Sports Economics, 1, 257-276.

15 France Football Review, no. 2990 bis, August 1, 2003, p. 20. 
Augustin, J. (1995). Sport, géographie et aménagement. Paris: Nathan.

Baade, R. (1996). An analysis of trends in the market for professional sports teams and stadiums: separating myth from reality, antitrust issues in relocation of professional sports franchises, hearing before the Senate Subcommittee on Antitrust, Business Rights, and Competition of the Committee of the Judiciary, Washington DC: United States Senate, p. D1396 (available from October 2003).

Baade, R., \& Matheson, V. (2001). Home run or wild pitch? The economic impact of major league baseball's all-star game. Fournal of Sports Economics, 2, 307-326.

Bale, J. (1993). Sport, space and the city. London: Routledge.

Behrens, A. (2003). Le produit intérieur brut régional dans l'Union Européenne en 2000. Eurostat: European Commission.

Bourg, J. (2003). Presented at the first IASE workshop, Regulation of labour market after Bosman case: socio-economic approach. Brive, February 6-7.

Bourg, J., \& Gouguet, J. (1998). Analyse économique du sport. Paris: Presses Universitaires de France.

Cagan, J. (1999). Field of schemes: How a great stadium swindle turned public money into private profit. New York: CPL.

Caiger, A., \& Gardiner, S. (Eds.) (2000). Professional sport in the European union: regulation and re-regulation. The Hague: TMC Asser Press

Coates, D., \& Humphreys, B. (1999). The growth effects of sport franchises, stadia, and arenas. Fournal of Policy Analysis and Management, 18, 601-624.

Cocco, A., \& Jones, J. (1997). On going south: The economics of survival and relocation of small market NHL franchises in Canada. Applied Economics, 29, 1537-1552.

Danielson, M. (2001). Home team: Professional sports and the American metropolis. Princeton: Princeton University Press.

Deloitte \& Touche (2002). Annual report on English football. Annual. Manchester: Deloitte \& Touche.

Durand, C. (1999). Concentration des firmes et clubs sportifs professionnels: quelle(s) stratégie(s) pour les villes moyennes? Sport Europe Stratégie, 2, 1-34.

Durand, C., \& Bayle, E. (2002). Public assistance in spectator sport: A comparison between Europe and the United States. European Fournal of Sport Sciences, 2.

El Hodiri, M., \& Quirk, J. (1974). The economic theory of a professional sports league. In R. Noll (Ed.), Government and the sport business. Washington DC: Brooking Institute.

El-Hodiri, M., \& Quirk, J. (1971). An economic model of a professional sports league. Fournal of Political Economy, 79, $1302-1319$.

Fort, R., \& Quirk, J. (Eds.) (2004). Owner objectives and competitive balance. Fournal of Sports Economics, 5(1), 2032. [Online at http://jse.sagepub.com/cgi/rapidpdf/5/1/20.pdf (accessed October 2005).]

Fort, R., \& Quirk, J. (1992). Pay dirt: The business of professionnal team sports. Princeton: Princeton University Press.

Gouguet, J.-J., \& Primault, D. (2003). Formation des joueurs professionnels et équilibre compétitif. Revue furidique et Economique du Sport, 68, 7-34.

Hoehn, T., \& Szymansky, S. (1999). The Americanization of European football. Economic Inquiry, 28, 205-233.

Jones, J., \& Walsh, W. (1988). Salary determination in the National Hockey League: The effect of skills, franchise characteristics, and discrimination. Industrial and Labor Relations Review, 41, 592-604.
Kesenne, S. (1996). League management in professional team sports with win maximizing clubs. European fournal for Sport Management, 2, 14-22.

Kesenne, S. (2000). Revenue sharing and competitive balance in professional team sports. Fournal of Sports Economics, 1, 56-65.

Kesenne, S. (2002). Improving the competitive balance and the salary distribution in professional team sports. In C. P. Barros, M. Ibrahâmo \& S. Szymanski (Eds.), Transatlantic sport: The comparative economics of North American and European sports (pp. 95-109). Cheltenham: Elgar.

Lavoie, M. (2003). Faut-il transposer à l'Europe les instruments de régulation du sport professionnel nord-américain? Revue Furidique et Économique du Sport, 67, 11-34.

Levin, R., Mitchell, G., Volcker, P., \& Will, G. (2000). The report of the independent members of the commissioner's blue ribbon panel on baseball economics. [Online at www.businessbase ball.com/docs/2000blueribbonreport.pdf (accessed October 2005).]

Ligue Football Professionnel (2002). Bilan Financier. Ligue Football Professionnel. [Online at www.footpro.fr/dncg/ (accessed October 2005).].

Longley, N. (1995). Salary discrimination in the National Hockey League: The effects of team location. Canadian Public Policy, XXI, 413-422.

Neale, W. (1964). The peculiar economics of professional sports: a contribution to the theory of the firm in sporting competition and in market competition. Quarterly fournal of Economics, 1, $1-14$.

Noll, R. (2002). The economics of promotion and relegation in sports leagues: The case of English football. Fournal of Sports Economics, 3, 168-203.

Noll, R., \& Zimbalist, A. (Eds.) (1997). Sports, jobs and taxes: The economic impact of sports teams and stadium. Washington DC: Brookings Institution.

Quirk, J., \& Fort, R. (1999). Hard ball: the abuse of power in pro team sports (Vol. 324). Princeton: Princeton University Press.

Ravenel, L. (1998). La géographie du football en France. Paris: Presses Universitaires de France.

Rosentraub, M. (1999). Majors league losers: The real cost of sport and who's paying for it. New York: Basic Books.

Ross, S. (1992). Break up the sports league monopolies. In P. Staudohar, \& J. Mangan (Eds.), The business of professional sports (pp. 152-174). Chicago: University of Illinois Press.

Scully, G. (1995). The market structure of sports. Chicago: University of Chicago Press.

Siegfried, J., \& Zimbalist, A. (2000). The economics of sports facilities and their communities. Fournal of Economic Perspectives, 3, 95-114.

Szymanski, S., \& Ross, S. (2000). Open competition in league sports. Wisconsin Law Review, 625-656.

Szymanski, S., \& Smith, R. (1997). The English football industry: Profit, performance and industrial structure. International Review of Applied Economics, 1, 135-53.

Vamplew, W. (1988). Pay up and play the game: Professional sports in Britain 1875-1914. Cambridge: Cambridge University Press.

Vrooman, J. (1995). A general theory of a professional sport league. Southern Economic fournal, 61, 971-994.

Walker, B. (1986). The demand for professionnal league football and the success of football league teams: some city size effects. Urban Studies, 23, 209-219. 